\title{
Hydrogen and Methane Breath Test in the Diagnosis of Lactose Intolerance
}

\author{
Charlotte De Geyter, Kris Van de Maele, Bruno Hauser and Yvan Vandenplas *
}

check for updates

Citation: De Geyter, C.; Van de

Maele, K.; Hauser, B.; Vandenplas, Y. Hydrogen and Methane Breath Test in the Diagnosis of Lactose Intolerance. Nutrients 2021, 13, 3261. https://doi.org/10.3390/nu13093261

Academic Editor: Dennis

Alan Savaiano

Received: 30 July 2021

Accepted: 15 September 2021

Published: 18 September 2021

Publisher's Note: MDPI stays neutral with regard to jurisdictional claims in published maps and institutional affiliations.

Copyright: (c) 2021 by the authors. Licensee MDPI, Basel, Switzerland. This article is an open access article distributed under the terms and conditions of the Creative Commons Attribution (CC BY) license (https:// creativecommons.org/licenses/by/ $4.0 /)$.
KidZ Health Castle, Vrije Universiteit Brussel (VUB) UZ Brussel, 1090 Brussels, Belgium; Charlotte.DeGeyter@uzbrussel.be (C.D.G.); Kristel.VanDeMaele@uzbrussel.be (K.V.d.M.); bruno.hauser@uzbrussel.be (B.H.)

* Correspondence: yvan.vandenpals@uzbrussel.be; Tel.: +32-475-748-794

Abstract: The hydrogen $\left(\mathrm{H}_{2}\right)$ breath test is a non-invasive investigation used to diagnose lactose intolerance (LI). Patients with LI may also expire increased amounts of methane $\left(\mathrm{CH}_{4}\right)$ during a lactose test. The aim of this study is to evaluate the contribution of $\mathrm{CH}_{4}$ measurements. We tested 209 children (1-17 years old) with symptoms suggesting LI with lactose $\mathrm{H}_{2}$ and $\mathrm{CH}_{4}$ breath tests. The result was positive when the $\mathrm{H}_{2}$ excretion exceeded 20 parts per million (ppm) and the $\mathrm{CH}_{4}$ was $10 \mathrm{ppm}$ above the baseline. A clinician, blinded for the results of the breath test, registered the symptoms. Of the patient population, 101/209 (48\%) were negative for both $\mathrm{H}_{2}$ and $\mathrm{CH}_{4}$; $96 / 209$ (46\%) had a positive $\mathrm{H}_{2}$ breath test result; $31 / 96$ (32\%) were also positive for $\mathrm{CH}_{4} ; 12 / 209$ (6\%) patients were only positive for $\mathrm{CH}_{4}$. The majority of hydrogen producers showed symptoms, whereas this was only the case in half of the $\mathrm{H}_{2}$-negative $\mathrm{CH}_{4}$ producers. Almost all patients treated with a lactose-poor diet reported significant symptom improvement. These results indicate that $\mathrm{CH}_{4}$ measurements may possibly be of additional value for the diagnosis of LI, since $5.7 \%$ of patients were negative for $\mathrm{H}_{2}$ and positive for $\mathrm{CH}_{4}$, and half of them experienced symptoms during the test.

Keywords: lactose intolerance; hydrogen breath test; methane

\section{Introduction}

Lactose intolerance is defined as the occurrence of symptoms such as abdominal pain, bloating, and diarrhea after the ingestion of lactose in patients with lactose malabsorption. Although congenital and secondary lactase deficiencies occur, most children suffer from a "primary late onset" [1] or "adult type" lactase deficiency due to the non-persistence of the enzyme lactase-phlorizin hydrolase after childhood [2].

Adequate amounts of lactase, present in the villi of the small intestinal brush border, are required for the digestion of lactose. However, if the lactase activity is insufficient, undigested lactose is fermented in the colon by anaerobic bacteria. In that case, lactose is metabolized into carbon dioxide (leading to bloating), methane $\left(\mathrm{CH}_{4}\right)$, propionic and butyric acids (short-chain fatty acids, leading to osmotic diarrhea), and hydrogen $\left(\mathrm{H}_{2}\right)$. Gasses such as $\mathrm{H}_{2}$ and $\mathrm{CH}_{4}$ accumulate in the intestine, but also pass through the intestinal wall into the bloodstream and are transported to the lungs, where they are excreted in the exhaled breath [3]. In humans, the only source of $\mathrm{H}_{2}$ and $\mathrm{CH}_{4}$ is their production by bacterial metabolism of carbohydrates [4].

When anamnesis is suggestive for lactose intolerance, $\mathrm{a}_{2}$ breath test is considered the golden standard for the diagnosis, as it is a safe, cost-effective, and non-invasive investigative tool [5] with a high sensitivity $(70-100 \%)$ and specificity $(69-100 \%)$ [6]. A meta-analysis by Marton, Xue, and Szilagyi [7] comparing the diagnostic accuracy of lactose $\mathrm{H}_{2}$ breath tests found an overall sensitivity of 0.88 (CI $\left.0.85-0.90\right)$ and specificity of 0.85 (CI $0.82-0.87) . \mathrm{A} \mathrm{H}_{2}$ increase of $20 \mathrm{ppm}$ above the baseline level is considered a positive test result, as suggested by the Rome Consensus Conference. In pediatric populations, a test duration of $3 \mathrm{~h}$ is advised, with samples taken at intervals of at least $30 \mathrm{~min}$ [8]. 
However, $2.5-15 \%$ of the $\mathrm{H}_{2}$ breath test results are false-negative due to a variety of causes, such as non-producers of $\mathrm{H}_{2}$ or increased production of $\mathrm{CH}_{4}$ [9-11]. It is known that the production of one mole of $\mathrm{CH}_{4}$ consumes four moles of $\mathrm{H}_{2}$ and one mole of carbon dioxide, thereby also reducing the intracolonic gas content [12]. From this perspective, multiple studies examined the concomitant determination of $\mathrm{CH}_{4}$ next to $\mathrm{H}_{2}$ in order to improve the diagnostic accuracy of the $\mathrm{H}_{2}$ breath test. A study by Vernia et al. [13] reported higher rates of false negative results in patients with predominant $\mathrm{CH}_{4}$ production, with a $\mathrm{CH}_{4}$ cut-off value of $10 \mathrm{ppm}$ above the baseline, compared to patients with low $\mathrm{CH}_{4}$ production. In other studies, significantly increased breath $\mathrm{CH}_{4}$ levels were found in both lactose intolerant children [14] and adults [15], and the combined breath test for $\mathrm{H}_{2}$ and $\mathrm{CH}_{4}$ is considered more appropriate for the diagnosis of lactose malabsorption [16]. However, other authors did not find any advantage of the concomitant measuring of $\mathrm{CH}_{4}$ [17]. Due to a lack of conclusive results in literature, the routine measurement of breath $\mathrm{CH}_{4}$ excretion is not currently advised, although it is suggested in the Rome Consensus that measuring $\mathrm{CH}_{4}$ excretion might improve diagnostic accuracy [8].

The aim of this pilot study is to evaluate the importance of the combined measurement of $\mathrm{H}_{2}$ and $\mathrm{CH}_{4}$ in the diagnosis of lactose intolerance.

\section{Materials and Methods}

Data were collected from November 2019 to July 2020 in the pediatric gastroenterology daycare unit of the KidZ Health Castle. Subjects were patients $<18$ years old, referred by a pediatrician for a lactose breath test because of reported symptoms suggestive of lactose intolerance. Parents and/or children (when old enough) gave permission to use the test results for this analysis. The history of the included patients was checked for the absence of evidence of small intestinal bacterial overgrowth, celiac disease, non-celiac gluten hypersensitivity, food allergy, or gastrointestinal infectious disease. Celiac disease was excluded because of the normal transglutaminase IgA antibodies in IgA sufficient children. The anti-gliadin IgG was within normal ranges in all children. The specific IgE for the common food allergies (egg white, cow milk, soy, fish, wheat, and gluten) was within normal ranges. The stool cultures, including parasites, were negative.

The tests were performed in the pediatric gastroenterology day-clinic after an overnight fasting time of at least $6 \mathrm{~h}$. A basal $\mathrm{H}_{2}$ measurement below $10 \mathrm{ppm}$ was set as a control of the fasting state. The pre-test conditions, according to the 2009 Rome Consensus Conference [8], were respected. Exercise and smoking before and during the test were avoided. The exclusion criteria were children who were not presumed healthy, or had a history of probiotic or antibiotic intake during the two weeks preceding the $\mathrm{H}_{2}$ breath test [18].

The lactose was administered orally (a dose of $2 \mathrm{~g} / \mathrm{kg}$, maximum $50 \mathrm{~g}$ ) and diluted in a maximum of $250 \mathrm{~mL}$ of water. The expired air was collected in specific gas-tight syringes with a capacity of $60 \mathrm{~mL}$. One breath sample was taken before the intake of lactose, and subsequent breath samples were collected in a sitting position every $15 \mathrm{~min}$ in a $3 \mathrm{~h}$ period after the ingestion of lactose. The patients were asked to remain in the waiting room and to avoid physical activity. The expired $\mathrm{H}_{2}$ and $\mathrm{CH}_{4}$ were measured with a specific analyzer (Microlyzer DP; Quintron Instruments, Milwaukee, WI, USA). The system was calibrated daily.

The result was considered positive when a $\mathrm{H}_{2}$ peak exceeded $20 \mathrm{ppm}$ above the baseline. The $\mathrm{CH}_{4}$ excretion was considered positive when reaching $10 \mathrm{ppm}$ above the baseline.

Gastro-intestinal symptoms such as abdominal pain, bloating, diarrhea, as well as extra-intestinal symptoms such as fatigue, headache, and dizziness, were registered every 15 min when a breath sample was collected. This was performed by a nurse, blinded for the results of the breath test.

The analyses were performed using SPSS version 26 . The statistical significance of the differences between the percentage of participants who were $\mathrm{CH}_{4}$ producers in various groups was determined by $\mathrm{chi}^{2}$ analysis. The significance of the correlations between 
the $\mathrm{CH}_{4}$ and $\mathrm{H}_{2}$ breath concentrations of producers vs. age was determined using the Spearman nonparametric correlation coefficient, because breath concentrations were not distributed normally.

\section{Results}

We tested 209 children with symptoms suggesting lactose intolerance with a lactose $\mathrm{H}_{2}$ and $\mathrm{CH}_{4}$ breath test. The mean age of our patients was 8.3 years (range 1.1-17.3 years, median 8.4 years, $\mathrm{SD} \pm 3.78$ ), including $56 \%$ girls and $44 \%$ boys. Over $90 \%$ reported gastrointestinal complaints, predominantly cramps or abdominal pain, flatulence, bloating, and diarrhea. In addition to the gastrointestinal complaints, a small proportion $(\sim 5 \%)$ also reported systemic complaints such as headaches.

In this group, 96 children (46\%) had a positive $\mathrm{H}_{2}$ breath test, of which $58 \%$ were girls. Of the female population, 65 of them (67.7\%) tested positive for $\mathrm{H}_{2}$, but showed no increased production of $\mathrm{CH}_{4}$. On the other hand, 31 out of $96(32.3 \%)$ patients had a positive test result for both $\mathrm{H}_{2}$ and $\mathrm{CH}_{4}$ excretion. In the group of $\mathrm{CH} 4$ producers, $48 \%$ were girls. It is interesting to note that $28 \%(12 / 43)$ of the $\mathrm{CH}_{4}$ producers had a negative result for $\mathrm{H}_{2}$ production. Children were classified with malabsorption when the breath test was positive but the child continued to show no symptoms. The rise in $\mathrm{H}_{2}$ or $\mathrm{CH}_{4}$ within the first hour did not occur in any of the children, which may have been indicative of small intestinal bacterial overgrowth [19].

Significantly more $\mathrm{CH}_{4}$ producers were present in the group of $\mathrm{H}_{2}$ producers (Table 1; 5.7 vs. $14.8 \%$; $\mathrm{CHI}$ square $<0.001$ ), which is in line with the theory that elevated amounts of $\mathrm{H}_{2}$ are necessary for production of $\mathrm{CH}_{4}$. In 10 children excreting high amounts of $\mathrm{CH}_{4}$ ( $>20 \mathrm{ppm}$ above baseline), 6 of them also tested positive for the $\mathrm{H}_{2}$ test. Only 2 of these 10 children were younger than 8 years old, suggesting that age might play a significant role in methanogenesis. Furthermore, we found age to be correlated significantly with baseline $\mathrm{CH}_{4}$ levels (Spearman.149, $p=0.031$ ) and with maximum $\mathrm{CH}_{4}$ (Spearman.142, $p=0.040$ ), but not with $\mathrm{H}_{2}$ values.

Table 1. Hydrogen $\left(\mathrm{H}_{2}\right)$ versus methane $\left(\mathrm{CH}_{4}\right)$ results.

\begin{tabular}{cccc}
\hline & $\mathbf{H}_{2}+$ & $\mathbf{H}_{2}-$ & Total \\
\hline & $31(14.8 \%)$ & $12(5.7 \%)$ & \\
$\mathrm{CH}_{4}+$ & $\mathrm{M}: 3$ & $\mathrm{M}: 6$ & $43(20.6 \%)$ \\
& I: 28 & $\mathrm{I}: 6$ & \\
$\mathrm{CH}_{4}-$ & $65(31.1 \%)$ & $101(48.3 \%)$ & $166(79.4 \%)$ \\
& M: 13 & $113(54.0 \%)$ & 209 \\
\hline
\end{tabular}

Legend: M: malabsorption; I: intolerance; $\mathrm{H}_{2}$ positive: peak exceeded 20 parts per million (ppm) over the baseline; $\mathrm{CH}_{4}$ positive: peak $>10$ ppm above baseline.

Prior to the administration of lactose, we found a mean breath $\mathrm{H}_{2}$ excretion of $19.7 \pm 20.9$ and a net $\mathrm{CH} 4$ excretion of $18.2 \pm 11.2$ (Table 2). No significant differences were seen in the baseline values of $\mathrm{H}_{2}$ or $\mathrm{CH}_{4}$ between normal and lactose malabsorbing children. After the administration of lactose, high elevations of breath $\mathrm{H}_{2}\left(\right.$ Delta $\left.\mathrm{H}_{2}>100\right)$ were seen, as expected in the lactose-intolerant children, but also in $\mathrm{CH} 4$ producers.

Significant correlations were found between delta $\mathrm{H}_{2}$ and delta $\mathrm{CH}_{4}$ values (P.358, $p<0.001$ ), delta $\mathrm{H}_{2}$ and max $\mathrm{CH}_{4}$ values (P.191, $p=0.005$ ), and between delta $\mathrm{CH}_{4}$ and max $\mathrm{H}_{2}$ values (P.312, $p<0.001$ ). This suggests that the elevations in $\mathrm{H}_{2}$ and elevations in $\mathrm{CH}_{4}$ coexist; this supports the hypothesis that $\mathrm{CH}_{4}$ production is dependent on a (minimum of) $\mathrm{H}_{2}$ production by conversion.

Overall, the difference in timing between $\mathrm{CH}_{4}$ and $\mathrm{H}_{2}$ peaks did not reach significance (median of $105 \mathrm{H}_{2}$ vs. $\left.120 \mathrm{CH}_{4} \min , p=0.058\right)$. There was no influence of $\operatorname{sex}(p=0.20)$ or age $(p=1)$. 
In total, 82 patients were treated with a lactose-free diet, and $56(68.3 \%)$ were reevaluated after 4 to 6 weeks. All but three patients reported significant improvement with the diet. These three patients had $\mathrm{CH}_{4}$ starting values between 16 and 34 ppm; one patient also had $\mathrm{a} \mathrm{H}_{2}$ baseline value $>20 \mathrm{ppm}$. At the follow-up consultation, the lactose-free diet was changed to a lactose-poor diet according to individual tolerance, and further follow-up was done by the referring physicians.

Table 2. Baseline and maximal values of $\mathrm{H}_{2}$ and $\mathrm{CH}_{4}$ in different groups.

\begin{tabular}{ccccc}
\hline & $\mathbf{H}_{\mathbf{2}} \mathbf{+}$ & $\mathbf{H}_{\mathbf{2}}-$ & $\mathbf{C H}_{\mathbf{4}}+$ & $\mathbf{C H}_{\mathbf{4}}-$ \\
\hline Baseline $\mathrm{H}_{2}$ & $21.3( \pm 22.1)$ & $18.5( \pm 19.9)$ & $15.1( \pm 12.5)$ & $21.2( \pm 22.8)$ \\
Max H $\mathrm{H}_{2}$ level & $142.4( \pm 101)$ & $21.2( \pm 21.4)$ & $120.0( \pm 106.6)$ & $59.3( \pm 80.8)$ \\
Delta $\mathrm{H}_{2}$ & $121( \pm 95.9)$ & $2.7( \pm 14.7)$ & $104.6( \pm 106.5)$ & $38.1( \pm 72.9)$ \\
Baseline $\mathrm{CH}_{4}$ & $17.5( \pm 8.9)$ & $18.8( \pm 12.7)$ & $21.4( \pm 15.1)$ & $17.2( \pm 9.3)$ \\
Max $\mathrm{CH}_{4}$ & $26.4( \pm 13.6)$ & $22.0( \pm 15.9)$ & $36.4( \pm 20.8)$ & $19.8( \pm 9.5)$ \\
Delta $\mathrm{CH}_{4}$ & $8.9( \pm 8.9)$ & $3.2( \pm 6.3)$ & $15.0( \pm 10.7)$ & $2.6( \pm 3.2)$ \\
\hline
\end{tabular}

Legend: max: maximal.

\section{Discussion}

In our study population, $14.8 \%$ of the children with a positive $\mathrm{H}_{2}$ breath test $(>20 \mathrm{ppm}$ above baseline) were also positive for $\mathrm{CH}_{4}$ (>10 ppm above baseline). Moreover, we detected significant $\mathrm{CH}_{4}$ production in $5.7 \%$ of the children with a negative $\mathrm{H}_{2}$ test, which is in line with the amount of false negatives (2.5-15\%) previously reported [9-11]. Houben et al. reported that the additional measurement of $\mathrm{CH}_{4}$ (considering an increase with $>5$ ppm as positive) improved the accuracy of the test, as $16 \%$ of subjects (out of 1051 patients, with 178 children) with normal lactose digestion and no $\mathrm{H}_{2}$ excretion were found to excrete $\mathrm{CH}_{4}$ [20]. In this study, a rise in ${ }^{13} \mathrm{CO}_{2}$ excretion was used as a standard to diagnose lactase deficiency [20]. Based on a retrospective analysis of 282 breath tests, Peron et al. concluded that merging $\mathrm{H}_{2}$ and $\mathrm{CH}_{4}$ stoichiometric values resulted in an increased sensitivity [21].

Almost all (53/56) children in our study indicated fewer gastrointestinal complaints when on a lactose-free diet, suggesting that they likely did suffer from lactose intolerance.

As excessive $\mathrm{CH}_{4}$ production is thought to cause more health consequences than an excess production of $\mathrm{H}_{2}$ [22], it is of high importance to detect these subjects. The $\mathrm{CH}_{4}$ levels in expired air are suggested to be related to constipation in patients with irritable bowel syndrome [22]. This hypothesis is indirectly endorsed by our finding that only half of the $\mathrm{CH}_{4}$ producers who did not produce $\mathrm{H}_{2}$ showed symptoms suggesting lactose intolerance, whereas this was the case in $80-90 \%$ of the $\mathrm{H}_{2}$ producers. However, some authors point out the difficulty of using reported symptoms during breath tests in the diagnosis of lactose intolerance, as they are often not reliable and/or poorly correlated [23,24].

Recently, instruments for the simultaneous measurement of $\mathrm{CH}_{4}$ and $\mathrm{H}_{2}$ have become more widely available for clinical use. Normally, patients produce either $\mathrm{H}_{2}$ or $\mathrm{CH}_{4}$, and coproducers were rarely identified when using older instruments [25]. However, with more modern detection systems, co-production is detectable even at low levels [22]. Ruzsanyi et al. [23] reported elevated $\mathrm{CH}_{4}$ levels in a majority of the children with a positive $\mathrm{H}_{2}$ breath test. Furthermore, since it is suggested that excessive $\mathrm{CH}_{4}$ production may cause more health consequences than an excess of $\mathrm{H}_{2}$ [22], it becomes even more important to measure $\mathrm{CH}_{4}$. In our study, $46 \%$ of the children demonstrated lactose malabsorption with a positive $\mathrm{H}_{2}$ breath test (of which $83 \%$ also reported symptoms compatible with LI). These data are comparable to other results in children [14,23], showing that $38 \%$ and $36 \%$, respectively, of the tested children had a positive $\mathrm{H}_{2}$ breath test. The ratio of boys and girls in the group with a positive $\mathrm{H}_{2}$ test was identical to the ratio of the entire study group. 
Background atmospheric $\mathrm{CH}_{4}$ is about $1.7 \mathrm{ppm}$. The subjects excreting more than 1 ppm of $\mathrm{CH}_{4}$ above the environmental value [26] are considered breath $\mathrm{CH}_{4}$-producers. Therefore, a threshold of $3 \mathrm{ppm}$ was proposed [27]. Others proposed a threshold of $10 \mathrm{ppm}[19,23]$, and in a recent study by Hammer et al. [28], malabsorption was defined by a net increase of $\geq 5$ to $\geq 12 \mathrm{ppm}$ for $\mathrm{CH}_{4}$, and $\geq 10$ to $\geq 15 \mathrm{ppm}$ for $\mathrm{H}_{2}$ plus $\mathrm{CH}_{4}$. In our group, $25 \%$ of the children showed elevated $\mathrm{CH}_{4}$ excretion of more than $10 \mathrm{ppm}$. It was stated that patients usually produce either $\mathrm{H}_{2}$ or $\mathrm{CH}_{4}$, and only rarely produce both [25]. Hammer et al. [28] also found that the addition of $\mathrm{CH}_{4}$ hardly influenced the results of malabsorption, and only under the use of specific cut-offs (the combined rise in $\mathrm{H}_{2}$ and $\mathrm{CH}_{4}$ should be less than 18) was a significant increase in the rate of malabsorbers seen. However, in our study, most of the $\mathrm{CH}_{4}$-positive tests $(72 \%)$ were found in the children that also demonstrated a positive $\mathrm{H}_{2}$ breath test. Medow et al. [14] also reported significantly increased breath $\mathrm{CH}_{4}$ levels in lactose intolerant children, although they already considered a $\mathrm{H}_{2}$ test positive from $10 \mathrm{ppm}$ above baseline. Schneider et al. [29] found a significant correlation between $\mathrm{CH}_{4}$ and $\mathrm{H}_{2}$ breath tests (Fisher's exact test, $p<0.001$ ), with a strong relationship (Phi coefficient: $\varphi=0.84, p<0.001$ ) and excellent agreement (Cohen's $\kappa=0.837$; $95 \%$ CI $0.682-0.992 ; p<0.001)$. Furthermore, they stated that it might be possible to detect non-hydrogen producers using a lower $\mathrm{CH}_{4}$ cut-off value (5 ppm), as it resulted in $26 \%$ more positive $\mathrm{CH}_{4}$ breath tests. Ruzsanyi et al. [23] reported elevated $\mathrm{CH}_{4}$ levels in a majority $(83 \%)$ of the children with a positive $\mathrm{H}_{2}$ breath test. It should be noted that in these studies, $\mathrm{CH}_{4}$ levels were considered to be elevated when exceeding the baseline by only $1 \mathrm{ppm}$. They reported elevated $\mathrm{CH}_{4}$ concentrations (>10 ppm above baseline) in $15 \%$ of the population, and an additional $28 \%$ of values greater than $1 \mathrm{ppm}$ above the baseline were seen. However, it must be noted that most of them already showed elevated values before the ingestion of lactose, which suggests that other factors are contributing to methanogenesis (e.g., small intestinal bacterial overgrowth (SIBO) [22], constipation [30], or constipation-predominant IBS [31]). Recently, Gottlieb et al. [32] confirmed significantly elevated $\mathrm{CH}_{4}$ levels in SIBO (confirmed with a lactulose breath test) and even proved a single-time-point $\mathrm{CH}_{4}$ breath sample taken after an overnight fast (without administration of substrate) to be equally accurate in diagnosing SIBO. There is also evidence that $\mathrm{CH}_{4}$ producers experience slower transit times [33], and higher $\mathrm{CH}_{4}$ excretion levels are seen in subjects suffering from constipation [34]. We found slightly later peak values in $\mathrm{CH}_{4}(120 \mathrm{~min})$ compared to $\mathrm{H}_{2}$ peaks $(105 \mathrm{~min})$, but this difference was not significant $(p=0.058)$. Possibly significant elevations of $\mathrm{H}_{2}$ could still occur after the test registration (after $180 \mathrm{~min}$ ).

The $\mathrm{CH}_{4}$ producing status depends on many influencing factors, such as age [35], sex [36], ethnic background [37,38], exercise [39], and gastrointestinal diseases [22,38]. $\mathrm{CH}_{4}$ is rarely identified in the breath of subjects less than three years of age [40-42], which is probably due to a later acquisition of a methanogenic microbiome [14]. $\mathrm{CH}_{4}$ production is considered to increase with age in an approximately linear way [35] until the adult distribution is reached [26]. However, others did not find any correlation between age and exhaled maximum $\mathrm{CH}_{4}$ concentration in children [23]. Furthermore, primary late onset lactose intolerance is characterized by a gradual reduction in lactase activity, and it generally manifests itself only after the age of 5 to 6 years of age in white populations, although it can occur earlier in predominantly non-white populations [1]. In general, it does not occur before the age of 2 years, which may explain why $\mathrm{CH}_{4}$ production and excretion is rarely seen in this age category. We found age to be correlated significantly with the start $\mathrm{CH}_{4}$ values (P.149, $p=0.031$ ) and with the maximum $\mathrm{CH} 4$ values $(\mathrm{P} .142, p=0.040$ ), but not with $\mathrm{H}_{2}$ values. However, some authors reported $\mathrm{CH}_{4}$ production already present in infants and toddlers $[25,43]$.

Several authors mention a female dominance in $\mathrm{CH}_{4}$ producers, certainly in young women $[35,36]$, but other studies did not find any significant difference between male and female $\mathrm{CH}_{4}$ producers $[26,44]$, and little is known about sex differences in $\mathrm{CH}_{4}$ excretion in children. No significant differences based on sex could be found in our study. 
Ethnic differences were not taken into account in our study, which is a shortcoming, as it might influence the $\mathrm{CH}_{4}$-producing status [37,38]. Furthermore, since the lactose-free diet intervention was open, and a blinded lactose challenge was not performed, a placebo effect cannot be excluded.

\section{Conclusions}

Although previous publications concluded that the addition of $\mathrm{CH}_{4}$ determination to the standard $\mathrm{H}_{2}$ measurement increases the sensitivity of a lactose breath test, the contribution of $\mathrm{CH}_{4}$ is still debated and not routinely performed. Our results confirm that the concomitant measurement of $\mathrm{CH}_{4}$ is of additional value for the diagnosis of $\mathrm{LI}$, since $5.7 \%$ of the children showed only an elevation of expired $\mathrm{CH}_{4}$, and half of these children were symptomatic during the breath test. Further research is needed before recommending systematic $\mathrm{CH}_{4}$ measurements.

Author Contributions: Conceptualization, K.V.d.M. and Y.V.; methodology, K.V.d.M. and Y.V.; software, C.D.G.; formal analysis, C.D.G.; investigation, K.V.d.M., B.H. and Y.V.; writing—original draft preparation, C.D.G.; writing—review and editing, Y.V. and B.H.; supervision, Y.V.; All authors have read and agreed to the published version of the manuscript.

Funding: This research received no external funding.

Institutional Review Board Statement: Ethical review and approval were waived for this study, due to the fact this manuscript reports data from investigations performed as good clinical practice.

Informed Consent Statement: Parents and patients (when old enough) gave perpission to analyse the data.

Data Availability Statement: Not applicable.

Conflicts of Interest: The authors declare no conflict of interest.

\section{References}

1. Vandenplas, Y. Lactose intolerance. Asia Pac. J. Clin. Nutr. 2015, 24 (Suppl. 1), S9-S13. [CrossRef]

2. Berni Canani, R.; Pezzella, V.; Amoroso, A.; Cozzolino, T.; Di Scala, C.; Passariello, A. Diagnosing and Treating Intolerance to Carbohydrates in Children. Nutrients 2016, 8, 157. [CrossRef]

3. Christl, S.U.; Murgatroyd, P.R.; Gibson, G.R.; Cummings, J.H. Production, metabolism, and excretion of hydrogen in the large intestine. Gastroenterology 1992, 102, 1269-1277. [CrossRef]

4. Simrén, M.; Stotzer, P.O. Use and abuse of hydrogen breath tests. Gut 2006, 55, 297-303. [CrossRef]

5. Di Camillo, M.; Marinaro, V.; Argnani, F.; Foglietta, T.; Vernia, P. Hydrogen breath test for diagnosis of lactose malabsorption: the importance of timing and the number of breath samples. Can. J. Gastroenterol. 2006, 20, 265-268. [CrossRef] [PubMed]

6. Romagnuolo, J.; Schiller, D.; Bailey, R.J. Using breath tests wisely in a gastroenterology practice: an evidence-based review of indications and pitfalls in interpretation. Am. J. Gastroenterol. 2002, 97, 1113-1126. [CrossRef] [PubMed]

7. Marton, A.; Xue, X.; Szilagyi, A. Meta-analysis: the diagnostic accuracy of lactose breath hydrogen or lactose tolerance tests for predicting the North European lactase polymorphism C/T-13910. Aliment. Pharmacol. Ther. 2012, 35, 429-440. [CrossRef] [PubMed]

8. Gasbarrini, A.; Corazza, G.R.; Gasbarrini, G.; Montalto, M.; Di Stefano, M.; Basilisco, G.; Parodi, A.; Usai-Satta, P.; Satta, P.U.; Vernia, P.; et al. Methodology and indications of H2-breath testing in gastrointestinal diseases: the Rome Consensus Conference. Aliment. Pharmacol. Ther. 2009, 29 (Suppl. 1), 1-49. [CrossRef] [PubMed]

9. Kerber, M.; Oberkanins, C.; Kriegshäuser, G.; Kollerits, B.; Dossenbach-Glaninger, A.; Fuchs, D.; Ledochowski, M. Hydrogen breath testing versus LCT genotyping for the diagnosis of lactose intolerance: A matter of age? Clin. Chim. Acta 2007, 383, 91-96. [CrossRef]

10. Eisenmann, A.; Amann, A.; Said, M.; Datta, B.; Ledochowski, M. Implementation and interpretation of hydrogen breath tests. J. Breath Res. 2008, 2, 046002. [CrossRef]

11. Lee, M.; Barrie, S. Breath testing in intestinal disaccharidase deficiency and bacterial overgrowth of the small intestine. J. Nutr. Environ. Med. 1996, 6, 43-54. [CrossRef]

12. Wolin, M.J. Fermentation in the rumen and human large intestine. Science 1981, 213, 1463-1468. [CrossRef]

13. Vernia, P.; Camillo, M.D.; Marinaro, V.; Caprilli, R. Effect of predominant methanogenic flora on the outcome of lactose breath test in irritable bowel syndrome patients. Eur. J. Clin. Nutr. 2003, 57, 1116-1119. [CrossRef] [PubMed]

14. Medow, M.S.; Glassman, M.S.; Schwarz, S.M.; Newman, L.J. Respiratory methane excretion in children with lactose intolerance. Dig. Dis. Sci. 1993, 38, 328-332. [CrossRef] [PubMed] 
15. Corazza, G.R.; Benati, G.; Strocchi, A.; Malservisi, S.; Gasbarrini, G. The possible role of breath methane measurement in detecting carbohydrate malabsorption. J. Lab. Clin. Med. 1994, 124, 695-700. [PubMed]

16. Waud, J.P.; Matthews, S.B.; Campbell, A.K. Measurement of breath hydrogen and methane, together with lactase genotype, defines the current best practice for investigation of lactose sensitivity. Ann. Clin. Biochem. 2008, 45, 50-58. [CrossRef] [PubMed]

17. Khin, M.; Bolin, T.D.; Oo, K.-M.; Oo, T.; Kyaw-Hla, S.; Thein-Myint, T. Ineffectiveness of breath methane excretion as a diagnostic test for lactose malabsorption. J. Pediatr. Gastroenterol. Nutr. 1999, 28, 474-479. [CrossRef]

18. Catanzaro, R.; Sciuto, M.; Marotta, F. Lactose intolerance: An update on its pathogenesis, diagnosis, and treatment. Nutr. Res. 2021, 89, 23-34. [CrossRef]

19. Rezaie, A.; Buresi, M.; Lembo, A.; Lin, H.; McCallum, R.; Rao, S.; Schmulson, M.; Valdovinos, M.; Zakko, S.; Pimentel, M. Hydrogen and Methane-Based Breath Testing in Gastrointestinal Disorders: The North American Consensus. Am. J. Gastroenterol. 2017, 112, 775-784. [CrossRef]

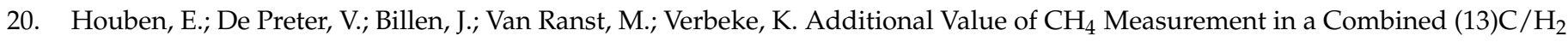
Lactose Malabsorption Breath Test: A Retrospective Analysis. Nutrients 2015, 7, 7469-7485. [CrossRef]

21. Peron, G.; Dall'Acqua, S.; Sorrenti, V.; Carrara, M.; Fortinguerra, S.; Zorzi, G.; Buriani, A. Retrospective analysis of a lactose breath test in a gastrointestinal symptomatic population of Northeast Italy: use of $\left(\mathrm{H}_{2}+2 \mathrm{CH}_{4}\right)$ versus $\mathrm{H}_{2}$ threshold. Clin. Exp. Gastroenterol. 2018, 11, 243-248. [CrossRef]

22. De Lacy Costello, B.P.; Ledochowski, M.; Ratcliffe, N.M. The importance of methane breath testing: a review. J. Breath Res. 2013, 7, 024001. [CrossRef] [PubMed]

23. Ruzsanyi, V.; Heinz-Erian, P.; Entenmann, A.; Karall, D.; Müller, T.; Schimkowitsch, A.; Amann, A.; Scholl-Bürgi, S. Diagnosing lactose malabsorption in children: Difficulties in interpreting hydrogen breath test results. J. Breath Res. 2016, $10,016015$. [CrossRef] [PubMed]

24. Hovde, Ø.; Farup, P.G. A comparison of diagnostic tests for lactose malabsorption-which one is the best? BMC Gastroenterol. 2009, 9, 82. [CrossRef]

25. Tormo, R.; Bertaccini, A.; Conde, M.; Infante, D.; Cura, I. Methane and hydrogen exhalation in normal children and in lactose malabsorption. Early Hum. Dev. 2001, 65, S165-S172. [CrossRef]

26. Bond, J.H.; Engel, R.R.; Levitt, M.D. Factors influencing pulmonary methane excretion in man. An indirect method of studying the in situ metabolism of the methane-producing colonic bacteria. J. Exp. Med. 1971, 133, 572-588. [CrossRef]

27. Basseri, R.J.; Basseri, B.; Pimentel, M.; Chong, K.; Youdim, A.; Low, K.; Hwang, L.; Soffer, E.; Chang, C.; Mathur, R. Intestinal methane production in obese individuals is associated with a higher body mass index. Gastroenterol. Hepatol. $2012,8,22-28$.

28. Hammer, K.; Hasanagic, H.; Memaran, N.; Huber, W.D.; Hammer, J. Relevance of Methane and Carbon Dioxide Evaluation in Breath Tests for Carbohydrate Malabsorption in a Paediatric Cohort. J. Pediatr. Gastroenterol. Nutr. 2021, 72, e71-e77. [CrossRef]

29. Schneider, C.; Wutzke, K.D.; Däbritz, J. Methane breath tests and blood sugar tests in children with suspected carbohydrate malabsorption. Sci. Rep. 2020, 10, 18972. [CrossRef]

30. Kunkel, D.; Basseri, R.J.; Makhani, M.D.; Chong, K.; Chang, C.; Pimentel, M. Methane on breath testing is associated with constipation: a systematic review and meta-analysis. Dig. Dis. Sci. 2011, 56, 1612-1618. [CrossRef] [PubMed]

31. Kim, G.; Deepinder, F.; Morales, W.; Hwang, L.; Weitsman, S.; Chang, C.; Gunsalus, R.; Pimentel, M. Methanobrevibacter smithii is the predominant methanogen in patients with constipation-predominant IBS and methane on breath. Dig. Dis. Sci. 2012, 57, 3213-3218. [CrossRef] [PubMed]

32. Gottlieb, K.; Le, C.; Wacher, V.; Sliman, J.; Cruz, C.; Porter, T.; Carter, S. Selection of a cut-off for high- and low-methane producers using a spot-methane breath test: results from a large north American dataset of hydrogen, methane and carbon dioxide measurements in breath. Gastroenterol. Rep. 2017, 5, 193-199. [CrossRef] [PubMed]

33. Lin, H.; Pimentel, M.; Chen, J. Intestinal transit is slowed by luminal methane. Neurogastroenterol. Motil. 2002, 14, 197-204. [CrossRef] [PubMed]

34. Furnari, M.; Savarino, E.; Bruzzone, L.; Moscatelli, A.; Gemignani, L.; Giannini, E.G.; Zentilin, P.; Dulbecco, P.; Savarino, V. Reassessment of the role of methane production between irritable bowel syndrome and functional constipation. J. Gastrointest. Liver Dis. 2012, 21, 157-163.

35. Polag, D.; Leiß, O.; Keppler, F. Age dependent breath methane in the German population. Sci. Total Environ. 2014, $481,582-587$. [CrossRef]

36. Triantafyllou, K.; Chang, C.; Pimentel, M. Methanogens, methane and gastrointestinal motility. J. Neurogastroenterol. Motil. 2014, 20,31-40. [CrossRef]

37. Mello, C.S.; Tahan, S.; Melli, L.C.; Rodrigues, M.S.; de Mello, R.M.; Scaletsky, I.C.; de Morais, M.B. Methane production and small intestinal bacterial overgrowth in children living in a slum. World J. Gastroenterol. 2012, 18, 5932-5939. [CrossRef]

38. Conway de Macario, E.; Macario, A.J. Methanogenic archaea in health and disease: a novel paradigm of microbial pathogenesis. Int. J. Med. Microbiol. 2009, 299, 99-108. [CrossRef]

39. Szabó, A.; Ruzsanyi, V.; Unterkofler, K.; Mohácsi, Á.; Tuboly, E.; Boros, M.; Szabó, G.; Hinterhuber, H.; Amann, A. Exhaled methane concentration profiles during exercise on an ergometer. J. Breath Res. 2015, 9, 016009. [CrossRef]

40. Bond, J.; Engel, R.; Levitt, M. Methane production in man. Gastroenterology 1970, 58, 1035.

41. Peled, Y.; Gilat, T.; Liberman, E.; Bujanover, Y. The development of methane production in childhood and adolescence. J. Pediatr. Gastroenterol. Nutr. 1985, 4, 575-579. [CrossRef] [PubMed] 
42. Sahakian, A.B.; Jee, S.R.; Pimentel, M. Methane and the gastrointestinal tract. Dig. Dis. Sci. 2010, 55, 2135-2143. [CrossRef] [PubMed]

43. Belson, A.; Shetty, A.K.; Yorgin, P.D.; Bujanover, Y.; Peled, Y.; Dar, M.H.; Reif, S. Colonic hydrogen elimination and methane production in infants with and without infantile colic syndrome. Dig. Dis. Sci. 2003, 48, 1762-1766. [CrossRef] [PubMed]

44. Levitt, M.D.; Furne, J.K.; Kuskowski, M.; Ruddy, J. Stability of human methanogenic flora over 35 years and a review of insights obtained from breath methane measurements. Clin. Gastroenterol. Hepatol. 2006, 4, 123-129. [CrossRef] 